\title{
Abnormal Vaginal Flora in Low-Risk Pregnant Women Cared for by a Public Health Service: Prevalence and Association with Symptoms and Findings from Gynecological Exams
}

\author{
Danielle Cristina Alves Feitosa Gondo ${ }^{1}$ \\ Marli Teresinha Cassamassimo Duarte $^{2}$ \\ Márcia Guimarães da Silva ${ }^{3}$ \\ Cristina Maria Garcia de Lima Parada ${ }^{4}$
}

\begin{abstract}
This study identifies the prevalence of vaginal flora alterations in low-risk pregnant women and their association with reported symptoms and gynecological exams. This quantitative, descriptive, cross-sectional study was conducted in public primary care service units in Botucatu, SP, Brazil from 2006 to 2008 with 289 pregnant women from a stratified sample obtained by sampling by care unit. Tests of vaginal content were performed using Gram's method and testing for Trichomonas vaginalis using Diamond's medium. The prevalence of altered vaginal flora was $49.5 \%$, of which bacterial vaginosis $(20.7 \%)$, vaginal candidiasis $(11.8 \%)$ and intermediate flora $(11.1 \%)$ were the most frequent, not considering associations. Results revealed a high prevalence of vaginal flora alterations with little relation to symptoms, but in agreement with findings from the gynecological exams. Considering undesirable maternal and perinatal outcomes and feasible laboratory practices, the establishment of a routine for diagnosing vaginal flora alterations in low-risk pregnant women is suggested.
\end{abstract}

Descriptors: Vaginosis, Bacterial; Candidiases, Vulvovaginal; Pregnancy; Prevalence.

\footnotetext{
${ }^{1}$ RN, M.Sc. in Nusing, Secretaria Municipal de Saúde de Botucatu, SP, Brazil. E-mail: dcafeitosa@hotmail.com.

2 RN, M.Sc. in Nursing, Assistant Professor, Faculdade de Medicina de Botucatu, Universidade Estadual Paulista "Júlio de Mesquita Filho", SP, Brazil. E-mail: mtduarte@fmb.unesp.br.

${ }_{3}^{3}$ Biologist, Ph.D. in Pathology, Assistant Professor, Faculdade de Medicina de Botucatu, Universidade Estadual Paulista "Júlio de Mesquita Filho", SP, Brazil. E-mail: mgsilva@fmb.unesp.br.

${ }^{4}$ RN, Ph.D. in Nursing, Adjunct Professor, Faculdade de Medicina de Botucatu, Universidade Estadual Paulista "Júlio de Mesquita Filho", SP, Brazil. E-mail: cparada@fmb.unesp.br.
}

Corresponding Author:

Cristina Maria Garcia de Lima Parada

Universidade Estadual Paulista "Júlio de Mesquita Filho". Faculdade de Medicina de Botucatu.

Departamento de Enfermagem

Campus Universitário de Rubião Júnior, s/n

Bairro Rubião Júnior

CEP: 18618-970 Botucatu, SP, Brasil

E-mail: cparada@fmb.unesp.br 


\section{Alteração de flora vaginal em gestantes de baixo risco, atendidas em serviço público de saúde: prevalência e associação à sintomatologia e achados do exame ginecológico}

Objetivou-se identificar a prevalência das alterações de flora vaginal em gestantes de baixo risco, sua associação à sintomatologia referida e exame ginecológico. É estudo quantitativo, descritivo e transversal, desenvolvido no serviço público de atenção básica de Botucatu, SP, no período de 2006 a 2008, com 289 gestantes, amostradas de forma estratificada por unidade. Realizou-se exame do conteúdo vaginal, utilizando-se coloração pelo método de Gram e pesquisa de Trichomonas vaginalis em meio líquido de Diamond. Desconsiderando-se as associações, a prevalência de flora vaginal alterada foi de $49,5 \%$, sendo as mais frequentes: vaginose bacteriana $(20,7 \%)$, candidíase vaginal $(11,8 \%)$ e flora intermediária $(11,1 \%)$. Os dados apontam elevada prevalência das alterações de flora vaginal, com pouca associação à sintomatologia, mas associação com achados do exame ginecológico. Considerando-se as repercussões maternas e perinatais indesejáveis e a prática laboratorial exequível, sugere-se o estabelecimento de rotina para diagnóstico das alterações de flora vaginal em gestantes de baixo risco.

Descritores: Vaginose Bacteriana; Candidíase Vulvovaginal; Gravidez; Prevalência.

\section{Alteración de la flora vaginal en gestantes de bajo riesgo atendidas en servicio público de salud: prevalencia y asociación a la sintomatología y hallazgos del examen ginecológico}

Se tuvo por objetivo identificar la prevalencia de las alteraciones de flora vaginal en gestantes de bajo riesgo, su asociación a la sintomatología referida y examen ginecológico. Estudio cuantitativo, descriptivo y transversal, desarrollado en el servicio público de atención básica de Botucatu/SP, en el período de 2006 a 2008, con 289 gestantes, el muestreo fue realizado de forma estratificada por unidad. Se realizó examen del contenido vaginal utilizándose coloración por el método de Gram e investigación de Trichomonas vaginalis en medio líquido de Diamond. Desconsiderándose las asociaciones, la prevalencia de flora vaginal alterada fue de $49.5 \%$, siendo las alteraciones más frecuentes: vaginitis bacteriana $(20.7 \%)$, candidiasis vaginal (11.8\%) y flora intermediaria $(11.1 \%)$. Los datos apuntan elevada prevalencia de las alteraciones de flora vaginal, con poca asociación a la sintomatología, pero con asociación a hallazgos del examen ginecológico. Considerándose las repercusiones maternas y perinatales indeseables y la práctica de laboratorio ejecutable, se sugiere el establecimiento de rutina para diagnóstico de las alteraciones de flora vaginal en gestantes de bajo riesgo.

Descriptores: Vaginosis Bacteriana; Candidíasis Vulvovaginal; Embarazo; Prevalencia.

\section{Introduction}

Bacterial vaginosis (BV) is a relevant issue during pregnancy because it is associated with a higher risk of late miscarriage, infection of the amniotic cavity, premature rupture of membranes, preterm labor, prematurity, and infant low birth weight ${ }^{(1)}$. The mechanism through which these obstetrical complications occur is not yet totally clarified, though it is known that BV consists of changes in vaginal flora, which produces endotoxins, making some women more vulnerable to inflammatory responses with the production of cytokines and prostaglandins that trigger labor. Microorganisms might ascend and invade the chorioamniotic membranes, decidua and amniotic fluid. Even the possibility of protease production by the microorganism that compose BV is possible, which would participate in the pathogenesis of the premature rupture of membranes ${ }^{(2)}$. 
It is also known that some bacterial species that colonize the Lower Genital Tract (LGT), especially those associated with $\mathrm{BV}$, release sialidase and prolidase. Sialidase are enzymes that cleave sialic acid from glycoproteins, among them the IgA, mucins and cell receptors and thus is associated with evasion of innate and acquired immunity, due to degradation of cervical IgA and changes in the cellular membrane receptors $^{(3)}$. Prolidase are proteolytic enzymes that degrade the extracellular matrix, encourage cell infiltration and thus contribute to breaking down the protective mucosal barrier(4). Women in the second trimester of pregnancy, with higher activities of sialidase and prolidase, accompanied by increased vaginal $\mathrm{pH}$, are at a higher risk of premature delivery because of the synergistic interrelationship among the virulence factors produced by bacteria in the altered vaginal microbiota with a consequent risk of an adverse pregnancy outcome ${ }^{(5)}$.

The metabolism resulting from the proliferation of these bacteria promote increased production of aromatic amines, the putrescine and cadaverine, which evaporate and induce a bad genital odor(6). Another frequent symptom is a grayish and fluid vaginal discharge with small bubbles ${ }^{(7)}$.

The Lactobacillus SP is a gram-positive bacillus that produces components such as lactic acid, bacteriocins and hydrogen, and which has properties that protect the vaginal flora. These components determine an acidic vaginal $\mathrm{pH}$, lower than 4.5, inhibiting the growth of pathogenic bacteria. The vaginal flora is also composed of other commensal microorganisms, which in certain situations can become pathogenic ${ }^{(8)}$.

We must take into account that under normal conditions, progesterone increases the number of intermediate epithelial cells, resulting in a higher availability of glycogen and decreased vaginal $\mathrm{pH}$. Even though these factors favor the presence of lactobacilli, they are also associated with the development of Candida $\mathrm{sp}^{(9)}$.

Vulvovaginal candidiasis is caused by several species of Candida sp, while Candida albicans is considered a commensal of the vaginal flora. The high levels of vaginal glycogen, and local heat and humidity, are conducive to fungus activation, especially in the second trimester of pregnancy. Its most common symptoms are itching, urinary discomfort, perineal irritation, and whitish discharge in plates, while between $25 \%$ and $40 \%$ of women are asymptomatic ${ }^{(10)}$. Although it is highly prevalent, it is not related to relevant perinatal complications ${ }^{(11)}$

Vaginal trichomoniasis is an important sexually transmitted disease, caused by Trichomonas Vaginalis (TV), an agent that mainly infects the LGT squamous epithelium. It is an anaerobic organism that grows well in the absence of oxygen, in $\mathrm{pH}$ between 5.0 and $5.7^{(12)}$.

Trichomoniasis symptoms depend on individual conditions, aggressiveness and the number of parasites and vary in intensity depending on the type of infection, which can be classified as acute or chronic. In acute cases, there is the classical sign of abundant, foamy, yellowish mucopurulent discharge ${ }^{(13)}$. This infection is related to various complications such as infertility, increased risk of HIV transmission, and undesirable pregnancy intercurrences such as the premature rupture of membranes, premature labor, and low birth weight newborns ${ }^{(12)}$.

Even though cytolytic vaginosis is not an infectious pathology, it is a condition frequently diagnosed as vaginal candidiasis because of its similar symptoms. Complaints reported by patients include whitish discharge, vaginal and vulvar itching, dyspareunia, dysuria, and perineal burning, markedly in the luteal phase of the menstrual cycle. These symptoms would be determined by the elimination of irritating substances from the cytoplasm of intermediate cells, arising from the cytolysis process from the action of lactobacilli. Diagnosis should include microscopic examination of samples directly from vaginal content through Gram's method, to exclude the possibility of infection by Candida $s p$, observing a significant increase of the number of lactobacilli, generally adhered to epithelial cells, which are also in a larger number, while leucocytes, when present, are $\operatorname{rare}^{(14)}$.

Aerobic vaginitis is associated with aerobic microorganisms, especially Streptococcus agalactiae and Escherichia coli, while its characteristics are different from those observed in bacterial vaginosis. Aerobic vaginitis raises an important inflammatory response that can cause complications during pregnancy such as ascendant chorioamnionitis, premature rupture of membranes and premature labor ${ }^{(15)}$.

Therefore, diagnosing and treating changes in the vaginal flora and their respective associations is especially relevant during pregnancy. Despite this relevance, health services frequently do not have the means to provide etiological treatment. Aiming to seek scientific evidence to base clinical practice during prenatal care, an important area of nursing practice ${ }^{(16-17)}$, this study's 
general objective is to identify the prevalence of vaginal flora alterations in low-risk pregnant women based on gold-standard tests and association with reported symptoms and gynecological exams.

\section{Method}

This quantitative, descriptive and cross-sectional study was carried out in Botucatu with approximately 120,000 inhabitants, located in the central region of the state of São Paulo, Brazil. The city has public primary health care delivered through three polyclinics, three health centers and two school center units and another eight Family Health Units with 10 teams. In addition to providing primary care within their scope areas, the polyclinics are also referral centers in pediatrics, gynecology and obstetrics, and general practice for the Family Health units and Health centers.

Based on a prevalence of altered vaginal flora of $20 \%$ with confidence interval of $95 \%$ and a margin of error of $5 \%$, the sample minimum size was determined by:

$$
n=\left(\frac{1.96 \sqrt{\hat{p}(1-\hat{p})}}{d}\right)^{2}=\left(\frac{1.96 \sqrt{0.20 \times 0.80}}{0.05}\right)^{2} \cong 245
$$

With a total of 1,006 pregnant women cared for in the various health units in 2005 , a stratified sample was obtained by unit, considering the coefficient:

$$
c=\frac{245}{1006}=0.2435
$$

Half way through the study, the prevalence found was used to recalculate the sample size. As the value obtained was lower than that initially computed, we opted for keeping the original computation.

A total of 289 pregnant women cared for during the prenatal period in the primary care public service in Botucatu, of any pregnancy stage, regardless of gynecological complaint, with at least 72 hours of sexual abstinence and/or vaginal procedures and absence of antibiotherapy in the 30 days prior to the collection were included in the study.

\section{Data Collection}

Data were collected from October 2006 to March 2008 by one of the authors. To characterize the studied women, socio-demographic information and personal and obstetrical antecedents were obtained.
Patients included in the study were submitted to speculum examination using a bi-valve vaginal Collins speculum, sterilized and without any lubricating. After this procedure, the macroscopic characteristics of the vaginal content were noted, followed by a $\mathrm{pH}$ measurement with Merk $^{\circledR}$ tape graduated between four and seven, pressed against the middle third of the lateral vaginal wall for one minute, then proceeding to the reading according to the manufacturer's instructions. Then, the material of the lateral vaginal wall was collected with a sterile swab and that content smeared onto glass slides. After this procedure, two drops of $10 \% \mathrm{KOH}$ were added to the swab with vaginal content to perform a Whiff test ${ }^{(18-19)}$.

Microscopy of vaginal content was performed using Gram's method. Collection of vaginal content for testing for TV was performed with an Ayre spatula and cultured in Diamond's medium(18-19).

The characteristics of vaginal content, a foul odor, vaginal itching, dyspareunia and bleeding after sexual intercourse were considered symptoms and signs when reported by the women ${ }^{(18-19)}$.

\section{Diagnosis of abnormal vaginal flora}

The proportion between Lactobacillus $S P$ and other microorganisms determine the type of vaginal microbiota: Flora I indicates there is a predominance of lactobacilli and diminished ancillary flora; Flora II is intermediary, with a diminished number of lactobacilli coexisting with other bacteria; and Flora II or bacterial vaginitis, occurs with marked diminished or absence of lactobacilli and predominance of bacterial morphotypes(20).

The diagnosis of Candidiasis was based on the presence of blastoconidia or pseudohyphae and neutrophils in the microscopy exam of the vaginal content stained by Gram's method. The diagnosis of aerobic $^{(15)}$ and cytolytic $^{(14)}$ vaginitis was also performed according to criteria previously mentioned.

Abnormal vaginal flora was defined as the absence or predominance of lactobacilli (BV and intermediate vaginal flora) or a positive culture for Candida $s p$ or TV through microscopy. Mixed flora was defined as positive for BV and VC, intermediate flora and TV and BV and trichomoniasis. All the slides with vaginal content were evaluated by an experienced examiner from the Universidade Estadual Paulista (UNESP) Medical Faculty with relative blinding concerning clinical data. 


\section{Studied variables}

The studied socio-demographic variables were: age (years), marital status (married, single, stable union and others), schooling (years), occupation and children (number). The following reported signs and symptoms were evaluated: discharge (yes, no); intensity (low, moderate, high), bad odor (yes, no, sometimes, does not know), genital itching (yes, no, sometimes, does not know), dyspareunia (yes, no, sometimes) and bleeding after intercourse (yes, not, sometimes).

The following were observed during the gynecological exam: vaginal discharge (yes, no), intensity (low, moderate, high), pH was measured, Wiff test or amines test was performed (positive, negative, dubious) and ectopia was observed (yes, no).

\section{Data analysis}

A database were created in the Excel and analyzed using the EpiInfo software. One of the researchers input the entire data and data consistency was checked through verification and comparison of the distribution of frequencies in associated questions; errors were corrected. Statistical analysis was performed through the $X^{2}$ test, whose level of significance was fixed at $\alpha=0.05$, with computation of respective odds ratio and confidence interval ( $\mathrm{CI}=95 \%)$. Whenever relevant, correction of Yates was performed.

\section{Ethical Procedures}

This study was evaluated and approved by the local Research Ethics Committee (of 85-2006-CEP) and complied with recommendations for research involving human subjects. After the study's objectives were clarified, women were invited to participate in the study and those who consented signed free and informed consent forms.

\section{Results}

The median age of the 289 pregnant women studied was 25 years (14-43). Most of the women reported they had a partner $(79.2 \%)$, nine of more years of schooling $(55.4 \%)$, no paid job (56.1\%) and $42.2 \%$ of them did not have children.

The prevalence of abnormal vaginal flora was $49.5 \%$ and the most frequent ones were

BV, VC and intermediate flora: $20.7 \%, 11.8 \%$ and $11.1 \%$, respectively, not considering associations. Mixed flora totaled $3.4 \%$ of the cases (Table 1 ).

Table 1 - Occurrence of abnormal vaginal flora in the studied pregnant women $(n=289)$. Botucatu, SP, Brazil 2008

\begin{tabular}{lcc}
\hline \multicolumn{1}{c}{ Vaginal Flora } & N & $\%$ \\
\hline Normal & 146 & 50.5 \\
Abnormal & 143 & 49.5 \\
Total & 289 & 100.0 \\
Prevalence of abnormal vaginal flora & & \\
Bacterial Vaginosis (BV) & 60 & 20.7 \\
Vaginal Candidiasis (VC) & 34 & 11.8 \\
Intermediate flora & 32 & 11.1 \\
Cytolytic vaginosis & 4 & 1.4 \\
Aerobic vaginitis & 2 & 0.7 \\
Trichomonas vaginalis (TV) & 1 & 0.4 \\
Mixed Flora & & \\
BV + CV & 7 & 2.4 \\
Intermediate flora + TV & 2 & 0.7 \\
BV + TV & 1 & 0.3 \\
\hline
\end{tabular}

Among the study's participants with abnormal vaginal flora, $69.9 \%$ reported discharge, $28.7 \%$ complained of bad genital odor, $29.4 \%$ itching, $28.7 \%$ dyspareunia and $4.9 \%$ complained of bleeding after recent sexual intercourse. There was an association only between itching and abnormal vaginal flora (Table 2).

Table 2 - Relationship between reported signs and symptoms and abnormal vaginal flora $(n=289)$. Botucatu, SP, Brazil 2008

\begin{tabular}{|c|c|c|c|c|c|c|c|c|}
\hline \multicolumn{9}{|c|}{ Abnormal vaginal flora } \\
\hline Signs and symptoms & Yes & $\%$ & No & $\%$ & Total & $\%$ & p-value & OR (CI 95\%) \\
\hline \multicolumn{9}{|l|}{ Discharge } \\
\hline Yes & 100 & 69.9 & 91 & 62.3 & 191 & 66.1 & 0.1723 & $1.4(0.9-2.3)$ \\
\hline No & 43 & 30.1 & 55 & 37.7 & 98 & 33.9 & & \\
\hline \multicolumn{9}{|l|}{ Bad odor } \\
\hline Yes & 41 & 28.7 & 30 & 20.5 & 71 & 24.6 & 0.1087 & $1.5(0.9-2.7)$ \\
\hline No & 102 & 71.3 & 116 & 79.5 & 218 & 75.4 & & \\
\hline \multicolumn{9}{|l|}{ Itching } \\
\hline Yes & 42 & 29.4 & 24 & 16.4 & 66 & 22.8 & 0.0088 & $2.1(1.2-3.7)$ \\
\hline No & 101 & 70.6 & 122 & 83.6 & 223 & 77.2 & & \\
\hline
\end{tabular}


Table 2 - (continuation)

\begin{tabular}{|c|c|c|c|c|c|c|c|c|}
\hline \multicolumn{9}{|c|}{ Abnormal vaginal flora } \\
\hline Signs and symptoms & Yes & $\%$ & No & $\%$ & Total & $\%$ & p-value & OR (CI 95\%) \\
\hline \multicolumn{9}{|l|}{ Dyspareunia } \\
\hline Yes & 41 & 28.7 & 35 & 24.0 & 76 & 26.3 & 0.3643 & $1.3(0.7-2.1)$ \\
\hline No & 102 & 71.3 & 111 & 76.0 & 213 & 73.7 & & \\
\hline \multicolumn{9}{|l|}{ Bleeding* } \\
\hline Yes & 7 & 4.9 & 4 & 2.7 & 11 & 3.8 & 0.5157 & $1.8(0.5-6.4)$ \\
\hline No & 136 & 95.1 & 142 & 97.3 & 278 & 96.2 & & \\
\hline
\end{tabular}

* Yates Correction

The gynecological exam among women with abnormal vaginal flora indicated vaginal content in $91.6 \%$ of cases, pH was normal in $30.1 \%$ of them, the Wiff test was positive for $36.4 \%$, and $41.3 \%$ presented ectopia. There was association between abnormal vaginal flora and vaginal content observed by the examiner, altered vaginal $\mathrm{pH}$, positive amines test and ectopia (Table 3).

Table 3 - Relationship between data of gynecological exams and abnormal vaginal flora $(n=289)$. Botucatu, SP, Brazil 2008

\begin{tabular}{|c|c|c|c|c|c|c|c|c|}
\hline \multicolumn{9}{|c|}{ Abnormal vaginal flora } \\
\hline Exam & Yes & $\%$ & No & $\%$ & Total & $\%$ & p-value & OR (Cl 95\%) \\
\hline \multicolumn{9}{|l|}{ Vaginal content } \\
\hline Yes & 131 & 91.6 & 108 & 74.0 & 239 & 82.7 & 0.0000 & $3.8(1.9-7.7)$ \\
\hline No & 12 & 8.4 & 38 & 26.0 & 50 & 17.3 & & \\
\hline \multicolumn{9}{|l|}{ Altered $\mathrm{pH}$} \\
\hline Yes & 100 & 69.9 & 23 & 15.8 & 123 & 42.6 & 0.0000 & $12.4(7.0-22.0)$ \\
\hline No & 43 & 30.1 & 123 & 84.2 & 166 & 57.4 & & \\
\hline \multicolumn{9}{|l|}{ Wiff test } \\
\hline Yes & 52 & 36.4 & 4 & 2.7 & 56 & 19.4 & 0.0000 & $20.3(7.1-58.0)$ \\
\hline No & 91 & 63.6 & 142 & 97.3 & 233 & 80.6 & & \\
\hline \multicolumn{9}{|l|}{ Ectopia } \\
\hline Yes & 59 & 41.3 & 82 & 56.2 & 141 & 48.8 & 0.0112 & $0.5(0.3-0.9)$ \\
\hline No & 84 & 58.7 & 64 & 43.8 & 148 & 51.2 & & \\
\hline
\end{tabular}

Analysis concerning BV evidenced that $66.2 \%$ of the pregnant women with this type of flora alteration complained of discharge; $20.6 \%$ and $29.4 \%$ of them reported itching and bad genital odor, respectively;
$92.6 \%$ of the women presented vaginal content in the gynecological exam; $94.1 \%$ presented altered $\mathrm{pH}$; and $70.6 \%$ a positive Wiff test (Table 4 ).

Table 4 - Relationship of reported signs and symptoms, data from the gynecological exam and BV $(n=289)$. Botucatu, SP, Brazil 2008

\begin{tabular}{|c|c|c|c|c|c|c|c|c|}
\hline \multicolumn{9}{|c|}{ VB } \\
\hline Variables & Yes & $\%$ & No & $\%$ & Total & $\%$ & $p$-value & OR (Cl 95\%) \\
\hline \multicolumn{9}{|c|}{ Signs and Symptoms } \\
\hline \multicolumn{9}{|l|}{ Discharge } \\
\hline Yes & 45 & 66.2 & 146 & 66.1 & 191 & 66.1 & 0.9862 & $1.0(0.6-1.8)$ \\
\hline No & 23 & 33.8 & 75 & 33.9 & 98 & 33.9 & & \\
\hline \multicolumn{9}{|l|}{ Itching } \\
\hline Yes & 14 & 20.6 & 52 & 23.5 & 66 & 22.8 & 0.6133 & $0.8(0.4-1.6)$ \\
\hline No & 54 & 79.4 & 169 & 76.5 & 223 & 77.2 & & \\
\hline \multicolumn{9}{|l|}{ Bad odor } \\
\hline Yes & 20 & 29.4 & 51 & 23.1 & 71 & 24.6 & 0.2886 & $1.4(0.7-2.5)$ \\
\hline No & 48 & 70.6 & 170 & 76.9 & 218 & 75.4 & & \\
\hline
\end{tabular}


Table 4 - (continuation)

\begin{tabular}{|c|c|c|c|c|c|c|c|c|}
\hline \multicolumn{9}{|c|}{ VB } \\
\hline Variables & Yes & $\%$ & No & $\%$ & Total & $\%$ & p-value & OR (Cl 95\%) \\
\hline \multicolumn{9}{|c|}{ Exam } \\
\hline \multicolumn{9}{|l|}{ Vaginal content* } \\
\hline Yes & 63 & 92.6 & 176 & 79.6 & 239 & 82.7 & 0.0216 & $3.2(1.2-8.5)$ \\
\hline No & 5 & 7.4 & 45 & 20.4 & 50 & 17.3 & & \\
\hline \multicolumn{9}{|l|}{ Altered $\mathrm{pH}^{*}$} \\
\hline Yes & 64 & 94.1 & 59 & 26.7 & 123 & 42.6 & 0.0000 & $43.9(15.3-125.9)$ \\
\hline No & 4 & 5.9 & 162 & 73.3 & 166 & 57.4 & & \\
\hline \multicolumn{9}{|l|}{ Wiff test } \\
\hline Positive & 48 & 70.6 & 8 & 3,6 & 56 & 19.4 & 0.0000 & $63.9(26.6-153.7)$ \\
\hline Negative & 20 & 29.4 & 213 & 96.4 & 223 & 80.6 & & \\
\hline
\end{tabular}

* Yates correction

The women with candidiasis reported $80.5 \%$ vaginal discharge, $56.1 \%$ itching and $43.9 \%$ bad genital odor. Vaginal content was observed during the gynecological exam in $90.2 \%$ of the women, altered $\mathrm{pH}$ in $61,0 \%$ and positive Wiff test in $14.6 \%$ (Table 5 ).

Table 5 - Relationship between reported signs and symptoms, data from the gynecological exam and candidiasis $(n=289)$. Botucatu, SP, Brazil 2008

\begin{tabular}{|c|c|c|c|c|c|c|c|c|}
\hline \multicolumn{9}{|c|}{ Candidiasis } \\
\hline Variables & Yes & $\%$ & No & $\%$ & Total & $\%$ & $p$-value & OR (Cl 95\%) \\
\hline \multicolumn{9}{|c|}{ Signs and Symptoms } \\
\hline \multicolumn{9}{|l|}{ Discharge } \\
\hline Yes & 33 & 80.5 & 158 & 63.7 & 191 & 66.1 & 0.0355 & $2.3(1.0-5.3)$ \\
\hline No & 8 & 19.5 & 90 & 36.3 & 98 & 33.9 & & \\
\hline \multicolumn{9}{|l|}{ Itching } \\
\hline Yes & 23 & 56.1 & 43 & 17.3 & 66 & 22.8 & 0.0000 & $6.1(3.0-12.2)$ \\
\hline No & 18 & 43.9 & 205 & 82.7 & 223 & 77.2 & & \\
\hline \multicolumn{9}{|l|}{ Bad odor $(n=282)^{*}$} \\
\hline Yes & 15 & 44.1 & 53 & 21.4 & 68 & 24.1 & 0.0036 & $2.9(1.4-6.1)$ \\
\hline No & 19 & 55.9 & 195 & 78.6 & 214 & 75.9 & & \\
\hline \multicolumn{9}{|c|}{ Exam } \\
\hline \multicolumn{9}{|l|}{ Vaginal content $^{\dagger}$} \\
\hline Yes & 37 & 90.2 & 202 & 81.5 & 239 & 82.7 & 0.2477 & $2.1(0.7-6.2)$ \\
\hline No & 4 & 9.8 & 46 & 18.5 & 50 & 17.3 & & \\
\hline \multicolumn{9}{|l|}{ Altered $\mathrm{pH}(\mathrm{n}=282)^{*}$} \\
\hline Yes & 18 & 52.9 & 98 & 39.5 & 116 & 41.1 & 0.1357 & $1.7(0.8-3.5)$ \\
\hline No & 16 & 47.1 & 150 & 60.5 & 166 & 58.9 & & \\
\hline \multicolumn{9}{|l|}{ Wiff test } \\
\hline Positive & 6 & 14.6 & 50 & 20.2 & 56 & 19.4 & 0.4068 & $0.7(0.3-1.7)$ \\
\hline Negative & 35 & 85.4 & 198 & 79.8 & 233 & 80.6 & & \\
\hline
\end{tabular}

* Cases of association with bacterial vaginosis were excluded

+ Yates correction.

\section{Discussion}

This study enabled the identification of the prevalence of abnormal vaginal flora in low-risk pregnant women, regardless of the reported complaint, using gold-standard exams with a sample of pregnant women from a medium sized city in the interior of São Paulo, Brazil.
Taking into account the general prevalence (49.5\%), the results reveal a high rate of abnormal vaginal flora, which is in agreement with other recent studies involving pregnant women ${ }^{(18-19)}$. BV was the most frequent alteration in the flora, with an isolated prevalence of $20.7 \%$ and $23.4 \%$ considering associations. These 
findings are consonant with other studies that indicate it is the most prevalent vaginal flora change in the world. Intermediate vaginal flora or Flora II was found in $21.6 \%$ of the women, a frequency much higher than that found in other studies: $13.1 \%{ }^{(21)}$ and $5.2 \%{ }^{(18)}$.

Candidiasis presented an isolated prevalence of $11.8 \%$ and $14.2 \%$ with associations, an value intermediate to those obtained in the same city by other authors: $34.5 \%{ }^{(19)}$ and $10.2 \%{ }^{(18)}$.

The prevalence of trichomoniasis, considering all cases, was low (1.4\%). It is believed that hyperdiagnosis and random treatment, especially of $\mathrm{BV}$, might be leading to a near eradication of the protozoan, which ends up being indirectly treated ${ }^{(21)}$.

The most frequent complaint of the women studied was vaginal discharge, reported by $66.1 \%$ of them, which is higher than the $51.6 \%$ reported by a study carried out with pregnant women from a peripheral area of an urban area in the south of Brazil(22). It is known that $20 \%$ or more women present mucoid and milky content during the gestational period, which wets the underwear without, however, constituting a pathological flow(23).

Even though vaginal discharge was the most frequent complaint among the pregnant women, it was not associated with the diagnosis of altered vaginal flora in this study. Similar to other studies' findings(21,23), other genital complaints such as bad odor, dyspareunia and bleeding after sexual intercourse were not associated with altered vaginal flora, either. Itching was associated with altered flora but one should consider that this symptom is frequently reported both in VC cases and in cytolytic vaginosis, whose treatments are distinct. Hence, the non-specificity of these signs and symptoms is apparent, suggesting that their presence does not contribute to the diagnosis of abnormal vaginal flora.

Taking into account all the women examined in this study, there was an association between observed vaginal content and abnormal vaginal flora. There was also an association between altered measured $\mathrm{pH}$ and alteration of vaginal flora, while the odds ratio obtained was 12 times greater $(\mathrm{OR}=12.4)$. A study conducted with pregnant women cared for in general prenatal care in an obstetrical outpatient clinic of a university hospital used vaginal $\mathrm{pH}$ for diagnosing $\mathrm{BV}$ and observed that $\mathrm{pH}$ was significantly higher in a group of pregnant women with such a diagnosis(24).

Ectopia was also associated with abnormal vaginal flora similar to the positive test of amines. However, some authors consider this test lacking the sensitivity for diagnosing BV, subjectivity is a disadvantage; its result depends on the examiner's personal interpretation ${ }^{(9)}$.

Specifically in relation to BV, there was not any association between reported signs and symptoms and abnormal vaginal flora, though, data from the gynecological exam indicated an association with the Amsel criteria(25).

There was association of all the reported symptoms - vaginal discharge, bad genital odor and itching - with VC, though when data from the gynecological exam were considered, no association was evidenced. We stress that the release of aromatic amines, accountable for the bad genital odor, does not occur in VC cases.

Taken as a whole, data from this study indicates a high prevalence of alterations in vaginal flora of low-risk pregnant women and that the reported symptoms were not associated or unexpected associated with these alterations, which might be explained by the subjectivity inherent to the perception of signs and symptoms. Thus, given the high prevalence, undesirable maternal and perinatal repercussions and feasible laboratorial practice, the establishment of a routine to diagnose alterations in the vaginal flora in low-risk prenatal care in outpatients is suggested.

\section{References}

1. Guerra B, Chi T, Quarta S, Morselli-Labate AM, Lazzarotto $T$, Pilu G, et al. Pregnancy outcome after early detection of bacterial vaginosis. Eur J Obstet Gynecol Reprod Biol. 2006; 128(1):40-5.

2. Fachini AM, Giraldo PC, Eleutério J Jr, Jacyntho C, Gonçalves AK, Linhares I. Vaginose bacteriana e trabalho de parto prematuro: uma Associação não muito bem compreendida. J Bras Doenças Sex Transm. 2005;17(2):149-52.

3. Cauci S, Monte R, Driussi S, Lanzafame P, Quadrifoglio F. Impairment of the mucosal immune system: IgA and IgM cleavage detected in vaginal washings of a subgroup of patients with bacterial vaginosis. J Infect Dis. 1998;178(6):1698-706.
4. McGregor JA, French JI, Jones W, Milligan K, McKinney PJ, Patterson E, et al. Bacterial vaginosis is associated with prematurity and vaginal fluid mucinase and sialidase: results of a controlled trial of topical clindamicyn cream. Am J Obstet Gynecol. 1994;170(4):1048-59.

5. Cauci S, McGregor J, Thorsen P, Grove J, Guaschino S. Combination of vaginal sialidase and prolidase activities for prediction of low birth weight and preterm birth. Am J Obstet Gynecol. 2005;192(2):489-96.

6. Peixoto $S$, Ramos LO. Vulvovaginites. In: Peixoto, S. Infecção genital na mulher. São Paulo (SP): Rocca; 2007. p. 59-87. 
7. Varma R, Gupta JK, James DK, Kilby MD. Do screeningpreventative interventions in asymptomatic pregnancies reduce the risk of preterm delivery - A critical appraisal of the literature. Eur J Obstet Gynecol Reprod Biol. 2006; 127(2):145-59.

8. Giraldo PC, Fachini AMD, Pereira RTG, Pereira S, Nowakonski AV, Passos MRL. A pertinência do Lactobacillus sp na flora vaginal durante o trabalho de parto prematuro. J Bras Doenças Sex Transm. 2006;18:200-3.

9. Simões JA, Discacciati MG, Silva MG. Flora vaginal normal e anormal. In: Peixoto S. Infecção genital na mulher. São Paulo: Roca; 2007. p. 27-36.

10. Giraldo PC, Simões JA, Duarte G. Doenças sexualmente transmissíveis. In: Neme B. Obstetrícia básica. São Paulo (SP): Sarvier; 2000. p. 481-503.

11. Simões JÁ. Complicações perinatais em gestantes assintomáticas com e sem infecções cervicovaginais [tese de doutorado]. Campinas (SP): Universidade de Campinas; 1997.

12. Maciel GP, Tasca T, Carli GA. Aspectos clínicos, patogênese e diagnóstico de Trichomonas vaginalis. J Bras Patol Med Lab. 2004;40(3):152-60.

13. Simões JA, Discacciati MG, Brolazo EM, Portugal PM, Dini DV, Dantas MCM. Clinical diagnosis of bacterial vaginosis. Int J Gynecol Obstet. 2006;94(1):28-32.

14. Cibley LJ, Cibley LJ. Cytolytic vaginosis. Am J Obstet Gynecol $1991 ; 165(4): 1245-9$

15. Donders GG. Definition of a type of abnormal vaginal flora that is distinct from bacterial vaginosis: aerobic vaginitis. BJOG 2002;109(1):34-43.

16. Dotto LMG, Moulin NM, Mamede MV. Prenatal care: difficulties experienced by nurses. Rev. Latino-Am. Enfermagem. [internet]. 2006. [acesso 31 ago 2009];14(5):682-8. Disponível em: http://www.scielo.br/scielo.php?script=sci_ arttext\&pid=S0104-11692006000500007\&lng=pt.doi:10.1590/ S0104-11692006000500007.
17. Feitosa DCA, Silva MG, Parada CMGL. Accuracy of simple urine tests for diagnosis of urinary tract infections in low-risk pregnant women. Rev. Latino-Am. Enfermagem. [internet]. 2009. [acesso 01 abril 2010];17(4):507-13. Disponível em: http://www.scielo.br/scielo.php?script=sci_arttext\&pid=S0104$1692009000400012 \&$ Ing $=$ pt. doi:10.1590/S0104 11692009000400012 .

18. Gondo F. Prevalência das infecções do trato genital inferior em gestantes de baixo risco da Estratégia de Saúde da Família da Atenção Primária em Saúde [dissertação de mestrado]. Botucatu (SP): Faculdade de Medicina de Botucatu da Universidade Estadual Paulista; 2007.

19. Tristão AR. Busca ativa e tratamento das infecções do trato genital inferior de gestantes com rastreamento positivo para diabete gestacional: repercussões maternas e perinatais [tese de doutorado]. Botucatu (SP): Faculdade de Medicina de Botucatu da Universidade Estadual Paulista; 2008.

20. Nugent RP, Krhon MA, Hillier SLL. Reliability of diagnosing bacterial vaginosis improved by standartization method of gram stain interpretation. J Clin Microbiol. 1991;29(2):297-301.

21. Gomes FAM. Valor do exame clínico especular e da anamnese para o diagnóstico do corrimento vaginal [tese de doutorado]. Campinas (SP): Universidade de Campinas; 2003.

22. Fonseca TMV, César JA, Hackenhaar AA, Ulmi EE, Neumann NA. Corrimento vaginal referido entre gestantes em localidade urbana no sul do Brasil: prevalência e fatores associados. Cad Saúde Pública. 2008;24(3):558-66.

23. Menezes ML, Faúndes AE. Validação do fluxograma de corrimento vaginal em gestantes. J Bras Doenças Sex Transm. 2004;16(1):38-44.

24. Carvalho MHB, Bittar RE, Maganha PPAS, Pereira SVP, Zugaib M. Associação da vaginose bacteriana com o parto prematuro espontâneo. Rev Bras Ginecol Obstet. 2001; 23(8):529-33.

25. Nugent RP, Krohn MA, Hillier SL. Reliability of diagnosing bacterial vaginosis is improved by a standardized method of gram stain interpretation. J Clin Microbiol. 1991; 29(2):297-301. 